\title{
Colon Cancer and Glioblastoma Multiforme Co-occurrence at an Early Age; A Case Report
}

\section{Erken Yaşta Kolon Kanseri ve Glioblastome Multiforme Birlikteliği; Olgu Sunumu}

\author{
Fatma Buğgdaycı Başal ${ }^{1}$, Umut Demirci ${ }^{1}$, Ahmet Şiyar Ekinci ${ }^{2}$, Muzaffer Altundağ ${ }^{3}$, Levent Gürses ${ }^{1}$, Ferit \\ Aslan $^{1}$, Ayşe Demirci ${ }^{1}$, Necati Alkış ${ }^{1}$ \\ ${ }^{1}$ Dr. A. Y. Ankara Onkoloji Eğitim Araştırma Hastanesi, Tıbbi Onkoloji Kliniği, Ankara, Türkiye \\ ${ }^{2}$ Dr. A. Y. Ankara Onkoloji Eğitim Araştırma Hastanesi, Radyasyon Onkolojisi Kliniği, Ankara, Türkiye \\ ${ }^{3}$ Dışkap1 Y1ldırım Beyazıt Eğitim Araştırma Hastanesi, Beyin Cerrahi Kliniği, Ankara, Türkiye
}

\section{ÖZET}

Kolon kanseri ve beyin tümörü birlikteliği klinikte karşımıza Muir-Torre Sendromu, Turcot Sendromu, Cowden Sendromu ya da Gardner Sendromu olarak çıkabilir. Turcot Sendromu multiple adenomatöz kolon polipleri ile santral sinir sisteminin (SSS) primer tümörünün birlikte görüldüğü DNA tamir genlerinde mutasyonlarla seyreden nadir bir hastalıktır. Biz bu olguda polipozis zemininde gelişen kolon kanseri tanısından üç yıl sonra glioblastome multiforme (GBM) tanısı alan fakat genetik çalışmada Turcot Sendromu desteklenemeyen genç bir kadın hastayı sunduk.

Anahtar Kelimeler: Kolon kanseri, Glioblastome multiforme; Turcot Sendromu

\section{ABSTRACT}

The co-occurrence of colon cancer and brain tumor can be observed as Muir-Torre syndrome, Turcot syndrome, Cowden syndrome or Gardner's syndrome, in clinical practice. Turcot syndrome is an uncommon disease with mutations in DNA repair genes that consist of multiple adenomatous colon polyps and central nervous system (CNS) tumor. We report a case of a young woman presents with polyposis related colon cancer who developes glioblastoma multiforme (GBM) three years after the diagnosis which cannot be explained with Turcot Syndrome by genetic studies.

Key words: Colon cancer, Glioblastoma multiforme; Turcot's Syndrome

\section{Giriş}

Kolon kanseri ve beyin tümörü birlikteliği klinikte karşımıza bazı sendromlarla çıkar. Muir-Torre Sendromu (sebasöz neoplazm, keratoakantom, viseral malignite, beyin tümörü), Turcot Sendromu (polipozis koli, beyin tümörü), Cowden Sendromu (serebellumda displastik gangliositom ve kolonda hamartomatöz polipler) ya da Gardner Sendromu (polipozis koli, osteom, mezenkimal tümör, kraniofarenjiom) bu iki kliniğin birlikte görüldüğü sendromlardır (1-4). Literatürde Muir-Torre Sendromu ile Turcot Sendromu'nun çakıştığı olgular bildirilmiştir $(1,5)$.

Turcot Sendromu multiple adenomatöz kolon polipleri ile santral sinir sisteminin (SSS) primer tümörünün birlikte görüldüğü nadir bir hastalıktır (6). İlk olarak 1949'da Crail tarafından tanımlanmış ve 1959 'da J. Turcot ve ark. tarafindan beyin tümörü ve polipozis coli birlikteliği olan iki kardeşte 'Turcot's Sendromu' şeklinde rapor edilmiştir (7). Tanı alan hastalar genellikle 10-20 yaş aralığındadır $(7,8)$. Turcot sendromunun genetik temeli karmaşık olup klinik ve genetik olarak çeşitli tiplerde kliniğe yansıyabilir. Literatürde yaklaşık 150 vaka bulunmaktadır (9-11). Biz bu olguda polipozis zemininde gelişen kolon kanseri tanısından üç yıl sonra glioblastome multiforme (GBM) tanisı alan genç bir kadın hastayı sunduk.

\section{Olgu Sunumu}

Yirmi iki yaşında kadın hasta Haziran 2011 yılında karın ağrısı nedeni ile yapılan 
kolonoskopisinde çekumda, transvers, inen, sigmoid kolonlarda ve rektosigmoid bölgede multipl sayıda polip saptanmıştı. Total kolektomi sonrasında multipl odakta iyi diferansiye adenokarsinom, çok sayıda tübülovillöz adenom ve 10 adet reaktif lenf nodu saptanmış ve adjuvan FUFA (5FU+ Folinik asit) tedavisi uygulanmıştı. Remisyonda izlenen hasta Aralık 2013'te sağ üst extremitede kuvvet kaybı gelişmesi üzerine diş merkezde çekilen beyin manyetik rezonans görüntülemesinde (MRG) sol frontal lobda 5.5 cm'lik kitle saptanmış (Resim 1) ve biyopsi yapılmış. Tanısal olmayan biyopsi sonras1 fokal epileptik nöbet geçiren hasta başka bir merkeze başvurmuş. Gros total olarak çıkartılan kitle (Resim 2) patolojisi GBM olarak raporlanan hasta idame tedavisi için hastanemize başvurdu. Özgeçmişinde kolon kanseri olan hastanın bir kız kardeşinin de beyin tümörü nedeniyle kaybedildiği öğrenildi.
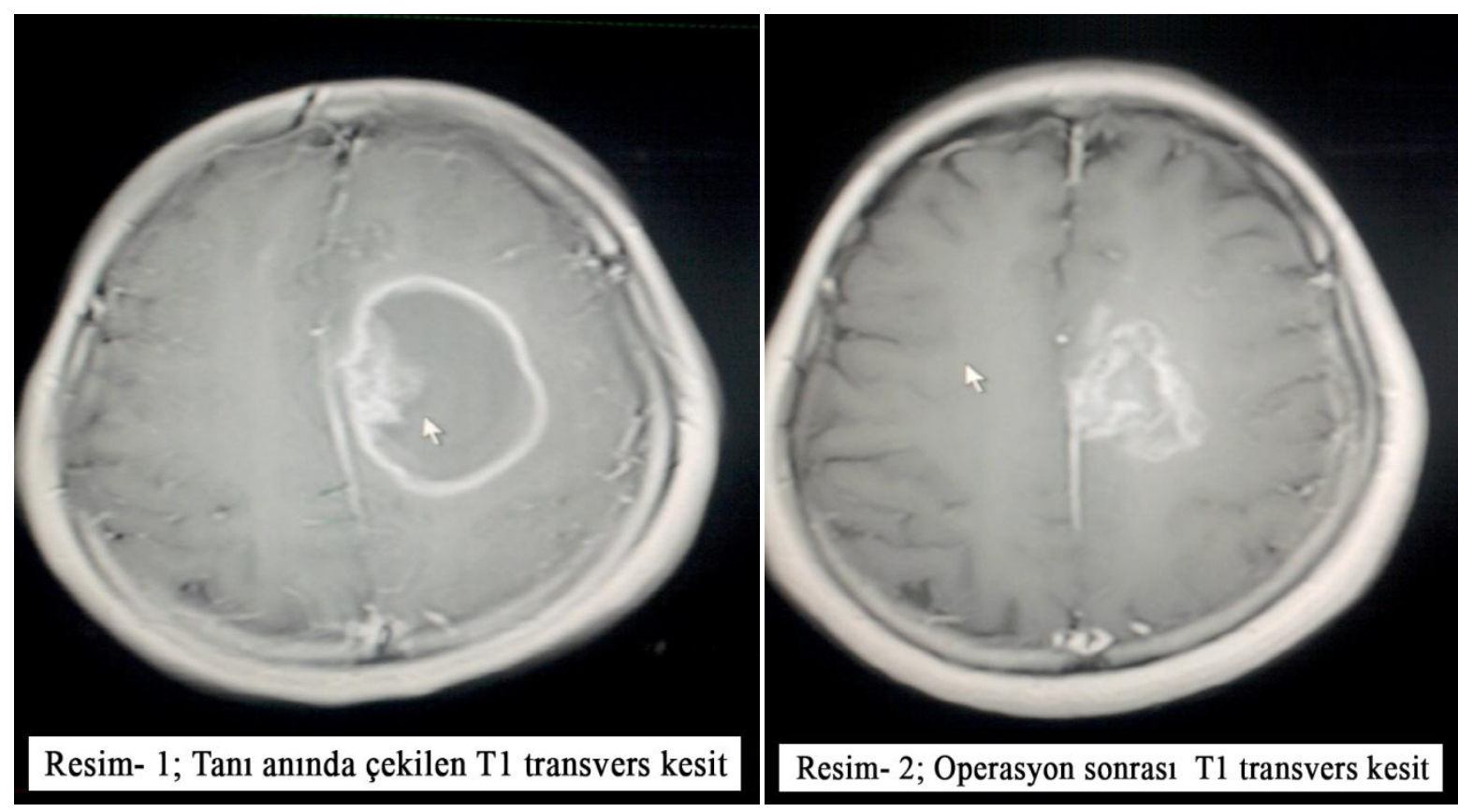

\section{Tartışma}

Olgumuz genç yaşta kolonda multipl polipler nedeniyle opere edilmesinin ardından iyi diferansiye adenokarsinom tanısı almış ve adjuvan tedavi sonrası remisyonda izlenirken GBM tanısı almıştır. $\mathrm{Bu}$ iki tümörün birlikteliği hastada Turcot Sendromu varlığını akla getirmektedir.

Herediter nonpolipozis koli (HNPC)

DNA tamir genlerinin (Mismatch Repair
Hastanın fizik muayenesinde sırtında akne benzeri lezyonları ve gövdede ve kollarda maküler kahverengi olmayan koyu renkli alanları vardı. Hastanın radyoterapi eş zamanlı temozolamid tedavisi sonrası idame temozolamid tedavisi tamamlandi. Hasta radyolojik ve klinik olarak progresyonsuz izlenmektedir.

Hastanın polipozis koli ve GBM tanıları birlikte ele alındığında Turcot Sendromu akla gelmekteydi. Bu nedenle hastanın kolon operasyonuna ait patoloji preparatları mikrosatellit instabilite (MSI) açısından immunohistokimyasal olarak değerlendirildi. Çalışmada neoplastik hücreler MLH1, PMS2, MSH6 ile pozitif olup MSH2 ile belirgin boyanma saptanmad. Kontrolünde de boyanma saptanmadığından MSH2 kayıp olarak değerlendirilmedi. Bu nedenle hastada DNA tamir genlerinin kaybına rastlanmad.
Genes; MMR) mutasyonundan kaynaklanır. HNPCC siklikla MSH2, MLH1 ve PMS2 genlerindeki mutasyondan kaynaklanır $(9,12)$. Olguların \%90'nında MSI görülür $(9,13)$. MSH2 mutasyonu siklıkla multipl tümör gelişimi ile ilişkilidir (14). Turcot sendromu modern literatürde beyin tümörü polipozis sendromu olarak bilinmektedir $(9,11)$. Nadir bir herediter hastalık olup HNPC ve familiyal adenomatozis polipozisin (FAP) varyantları olarak görülür (12). Tip 1 ve tip 2 olmak üzere 
iki farklı klinikte karşımıza çıkar. Tip 1 otozomal resesif geçişli olup, HNPC ve sıklıkla GBM olmak üzere beyin tümörleri birlikteliği ile görülür. Tip 2 ise otozomal dominant geçişli olup FAP ve medulloblastom birlikteliği ile görülür. $\mathrm{Bu}$ iki tip sendrom arasında kesin bir ayrım yoktur. Tip 1'de kolon poliplerinin sayıs 100 'den azdır ve beyin tümörleri gliomlar şeklinde görülür. Tip 2 Turcot Sendromu'nda kolonda polipler yüzler hatta binlere ulaşmakta ve $\% 20$ vakada kolorektal kansere rastlanmaktadır. Beyinde medulloblastom \%60 vakada görülür (911,15). Bu anlamda bizim olgumuz tip 1 Turcot Sendromu'nu akla getirmektedir fakat yapilan incelemede MMR genlerinde mutasyona rastlanmamıştır.

Kolonik ve serebral semptomlar ayn anda ortaya çıabileceği gibi birbirini de takip edebilir. İlk semptom ortaya çıtıktan sonra beş y1l içinde diğer semptomlar kendini gösterir (7). Genellikle barsak lezyonları beyin tümörü tanısından bir yıl sonra başgösterir yada postmortem saptanır (6). Ayrica kolon rezeksiyonundan 2-8 y1l sonra da SSS malignitesi ortaya çıkabilir $(6,15)$. Bizim olgumuzda da kolon kanseri tanısı aldıktan üç y1l sonra serebral semptomlar ortaya çıkmıştır. Cinsiyet ve rrk eğilimi bilinmemektedir fakat 10-30 yaşları arasında görülür (6). Kliniğe yansıması spesifik değildir. Pigmente nevüs, kafeola, bazal hücreli karsinoma gibi deri bulguları görülür $(9,11)$. Bizim olgumuzda da sirtta akne benzeri lezyonlar, gövde ve kollarda kahverengi olmayan koyu renkli makuler lezyonlar1 mevcuttu.

Olgumuz tip 1 Turcot Sendromu kliniğine uyması ve aile hikayesinin olması itibariyle genetik incelemeyi haketmiş ilginç bir hastadır. Fakat Türkiye'den literatürde varolan herhangi bir Turcot olgusu olmadiğı gibi bizim olgumuzda da Turcot Sendromu'nu destekleyecek MMR genlerine rastlanmamıştır. Yine de bu hasta grubu eşlik edebilen multipl tümörler nedeni ile yakın izlenmelidir.

\section{Çıkar Çatışması: Yok}

\section{Kaynaklar}

1. Grandhi R, Deibert CP, Pirris SM, Lembersky B, Mintz AH. Simultaneous Muir-Torre and Turcot's syndrome: A case report and review of the literature. Surg Neurol Int 2013; 4: 52

2. Park MD, Yeaney GA, Hamilton RL, Mabold J, Urban N. Identifying Muir-Torre syndrome in a patient with glioblastoma multiforme. Neuro Oncol (August 2009) 11 (4): 452-455

3. Yuasa H, Motokishita T, Tokito S, Tokunaga M, Goto M. Lhermitte-Duclos disease associated with Cowden's disease-case report. Neurol Med Chir (Tokyo) 1997 Sep;37(9):697-700

4. Bozbuga M, Suslu HT, Hicdonmez T, Bayindir Ç. Primary cerebellopontine angle craniopharyngioma in a patient with Gardner syndrome. Journal of Clinical Neuroscience Volume 18, Issue 2, February 2011, Pages 300-301

5. Kleinerman R, Marino J, Loucas E. Muir-Torre Syndrome / Turcot Syndrome overlap? A patient with sebaceous carcinoma, colon cancer, and a malignant astrocytoma. Dermatology Online Journal 18 (5): 3

6. Radin DR, Fortgang KC, Zee CS, Mikity VG, Halls JM. Turcot syndrome: a case with spinal cord and colonic neoplasms. AJR Am J Roentgenol 1984 Mar;142(3):475-6

7. Ma S, Hu Y, Yang J, Zhou X. Turcot's syndrome associated with intestinal non-Hodgkin's lymphoma: case report and review of literature. Clin Neurol Neurosurg 2013 Feb;115(2):117-20

8. McLaughlin $\mathrm{MR}^{1}$, Gollin SM, Lese CM, Albright AL. Medulloblastoma and glioblastoma multiforme in a patient with Turcot syndrome: a case report. Surg Neurol 1998 Mar;49(3):295-301

9. Ozerov SS, Zakharov IV, Talypov SR, Konovalov DM, Kisliakov AN. Turcot syndrome: Rare observation and literature review. Zh Vopr Neirokhir Im N N Burdenko 2013;77(3):49-53

10. Hamilton SR, Liu B, Parsons RE, Papadopoulos N, Jen J, et al. The molecular basis of Turcot's syndrome. N Engl J Med 1995 Mar 30;332(13):83947

11. Paraf F, Jothy S, Van Meir EG. Brain tumorpolyposis syndrome: two genetic diseases? JCO Jul 1, 1997:2744-58

12. Lebrun C, Olschwang S, Jeannin S, Vandenbos F, Sobol H. Turcot syndrome confirmed with molecular analysis. Eur J Neurol 2007 Apr;14(4):470-2

13. De Vos M, Hayward BE, Picton S, Sheridan E, Bonthron DT. Novel PMS2 pseudogenes can conceal recessive mutations causing a distinctive childhood cancer syndrome. Am J Hum; Genet 2004 May;74(5):954-64

14. Balaguer F, Cervantes A, Arnold D. Familial riskcolorectal cancer: ESMO Clinical Practice Guidelines. Balmaña J, ESMO Guidelines Working Group. Ann Oncol 2013 Oct;24 Suppl 6:vi73-80

15. Itoh $\mathrm{H}$, Ohsato $\mathrm{K}$, Yao $\mathrm{T}$, Iida $M$, Watanabe $H$. Turcot's syndrome and its mode of inheritance. Gut 1979 May;20(5):414-9 